\title{
Poly [ADP-Ribose] Polymerase 1
}

National Cancer Institute

\section{Source}

National Cancer Institute. Poly [ADP-Ribose] Polymerase 1. NCI Thesaurus. Code C48215.

Poly [ADP-ribose] polymerase $1(1013 \mathrm{aa}, \sim 113 \mathrm{kDa}$ ) is encoded by the human PARP1 gene. This protein is involved in poly ADP-ribosylation and in the regulation of various cellular processes such as differentiation, proliferation, tumor transformation, and recovery from DNA damage. 